\title{
航空機向けチタン合金とその鍛造技術
}

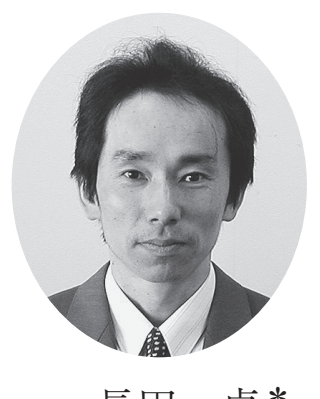

長田 卓*

\begin{abstract}
Journal of The Japan Institute of Light Metals, Vol. 65, No. 9 (2015), 460-465 (c) 2015 The Japan Institute of Light Metals
\end{abstract}

\section{Technology for process design of titanium alloy forging}

\author{
Takashi CHODA*
}

Keywords: titanium alloy, forging, aircraft, $\beta$-process, finite element analysis

\section{1. 緒言}

チタン合金は, 比強度 ( $=0.2 \%$ 耐力/密度) において他の 金属素材より優れており，世界で使用されているチタン合金 鍛造品の $50 \%$ 以上は軽量化と強度が要求される航空機向け 部材である ${ }^{1)}$ 。

民間航空機市場は近年旺盛な旅客需要を背景に年率 4 $5 \%$ で拡大しており, リプレイスを含めると今後 20 年間で現 在の 2 倍以上の機数の航空機が必要になると予想されてい る2)。さらに，航空機 1 機あたりに使用されるチタン合金の 使用割合は近年増加しており, チタン合金鍛造品の需要は増 大傾向にある。

一方，チタン合金は一般的に難鍛造材料であると言われて おり, 金型への充満性が低く, 形状を確保することが難し い。さらに, 航空機向けチタン合金鍛造品, なかでもエンジ ンディスク, シャフトなどの回転体部品では, 高い信頼性が 要求され, 鍛造時の温度, ひずみ, ひずみ速度を制御して材 料特性および品質検査の仕様を達成することが必要である。

また, チタン合金は他の金属素材と比較して, 原料が高価 なことに加えて，被削性（機械加工性）が悪く，加工費も高 い。そのため, 航空機用途以外も含めた需要拡大のためには, 鍛造技術の観点からは，品質を確保しつつ，ニアネット化し て歩留を高めることも重要となる。

本稿では, 文献3）をもとに, 航空機向けチタン合金部品 の鍛造技術について述べる。

\section{2. 航空機に用いられているチタン合金鍛造品}

チタン合金鍛造品は, 様々な航空機機体構造部品およびエ ンジン部品に使用されている。Boeing787型機の構造部材と して, チタン合金の比率は鍛造材以外も含めて約 $15 \%$ と従 来機種の 2 倍以上になり, 1 機あたりチタン合金の使用量（推
定）は $100 \mathrm{t}$ 前後になる ${ }^{2)}$ 。これは機体重量削減による燃費改 善のため, アルミニウム合金に代わり大量に使用されるよう になった炭素繊維強化樹脂（CFRP）に対して, チタン合金 の適合性がよいためである。チタン合金はCFRP 部材と締結 してもガルバニック腐食が生じにくく，また，CFRPと熱膨 張率が近いために温度変化によるひずみを抑制できる。

機体構造部品に用いられる一般的なチタン合金は, Ti6Al-4V（略称 Ti-64）合金であり，80９0\%を占める。Ti-64 は最も汎用的な $\alpha-\beta$ 合金で, 各種特性のバランスがよく, こ れまでの豊富なデー夕，実績がある。

一方, 機体構造部品の中でもランディングギアと呼ばれる 航空機の脚部には, およそ200〜400トンもの重量の中大型 航空機を支え, かつ着陸時の衝撃に耐える必要があるため, 高強度・高勒性の材料が求められる。現行 $\mathrm{NiCrMo}$ 鋼が主流 であるが, Boeing777型機やエアバス社 A380型機ではNear $\beta$ （ $\alpha-\beta$ 合金の中で $\beta$ 安定化元素濃度が高い合金）の高強度于 タン合金 Ti-10V-2Fe-3Al, また Boeing787 型機では Ti-5Al$5 \mathrm{Mo}-5 \mathrm{~V}-3 \mathrm{Cr}$ といった新しい合金が適用されている4)。これ らのチタン合金はTi-64より高価であるが, 鍛造性に優れる とともに, 鍛造後に溶体化時効処理を行うことで, 強度を向 上させることができる。

航空機エンジンでは, 使用温度が $590^{\circ} \mathrm{C}$ 以下のファンや

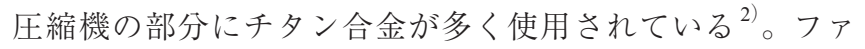
ンディスクや低圧圧縮機ディスクにはTi-64合金が用い られ, 中圧圧縮機ディスクにはNear $\beta$ の Ti-6Al-2Sn-4Zr$6 \mathrm{Mo}$ (Ti-6246) 合金や Ti-5Al-2Sn-2Zr-4Cr-4Mo（Ti-17）合金 を溶体化時効処理したものが使用される。さらに, 高温とな る高圧圧縮機ディスクにはNear $\alpha(\alpha-\beta$ 合金の中で $\beta$ 安定化 元素濃度が低い合金）の Ti-5.8Al-4Sn-3.5Zr-0.7Nb-0.5 Mo$0.35 \mathrm{Si}$ 合金（IMI834）などの耐熱チタン合金鍛造品が使用さ れている。ファンや圧縮機のディスク, シャフト, ブレード

\footnotetext{
*株式会社神戸製鋼所 鉄鋼事業部門 チタン本部 チタン研究開発室（† 676-8670 兵庫県高砂市荒井町新浜 2-3-1） Titanium Research \& Development Section Manager, Titanimum Division, Iron \& Steel Business, KOBE STEEL, LTD. (2-3-1 Shinhama Arai-cho, Takasago-shi, Hyogo, 676-8670) E-mail: choda.takashi@kobelco.com
}

受付日：平成27年3月 11 日 受理日：平成27年 4 月 16 日 
などの回転体には, 静的強度に加えて, 疲労強度, 破壊勒性 のほか, 超音波探傷試験（UT）における欠陷検出のしやす さなど，様々な特性が高いレベルで要求される5）。

\section{3. チタン合金の熱間鍛造特性}

チタン合金は図 1 に示すように, 添加元素の種類と添加量

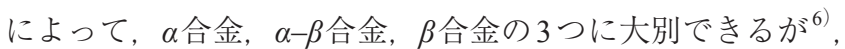
最も一般的に使用されているのは $\alpha-\beta$ 合金である。いずれの 合金も結晶構造が最密六方格子の $\alpha$ 相と体心立方格子の $\beta$ 相 の 2 相から形成され，各相の量やサイズ，形態が異なること で，鍛造性や機械的特性に大きな違いが生じる。 Mo, V, Cr, $\mathrm{Fe}$ な゙の $\beta$ 安定化元素が多いほど $\beta$ 相が多くなり, 一般的に 鍛造性がよくなる。一方, $\beta$ 安定化元素が多くなり過ぎると

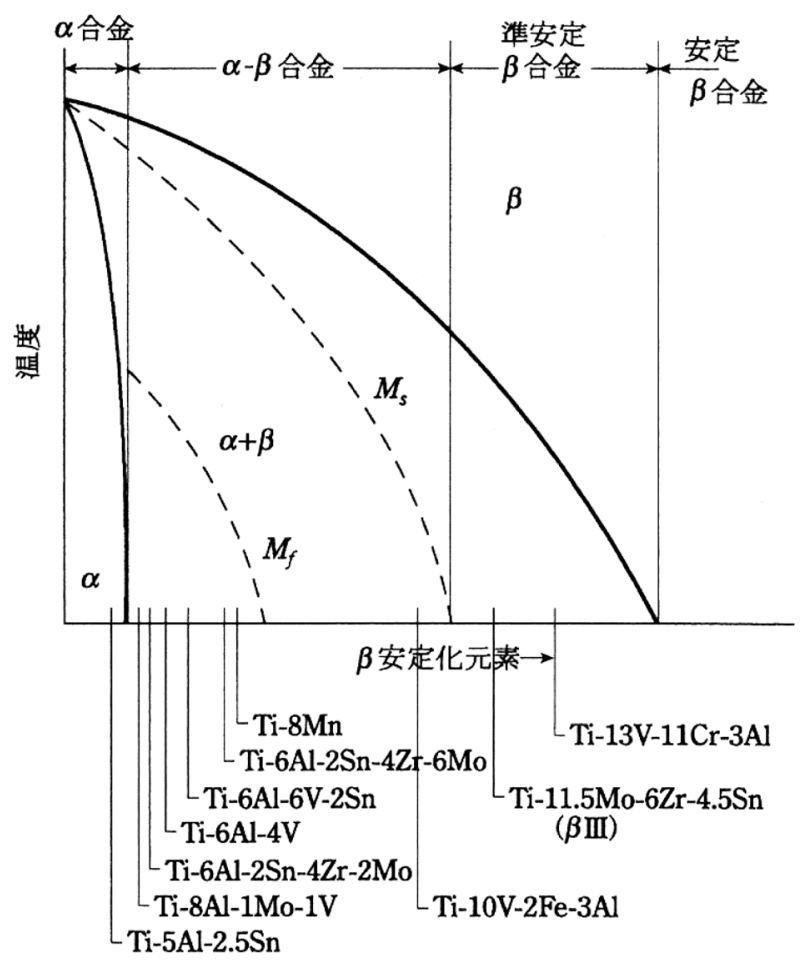

図 1 チタン合金の種類と状態図 ${ }^{6)}$

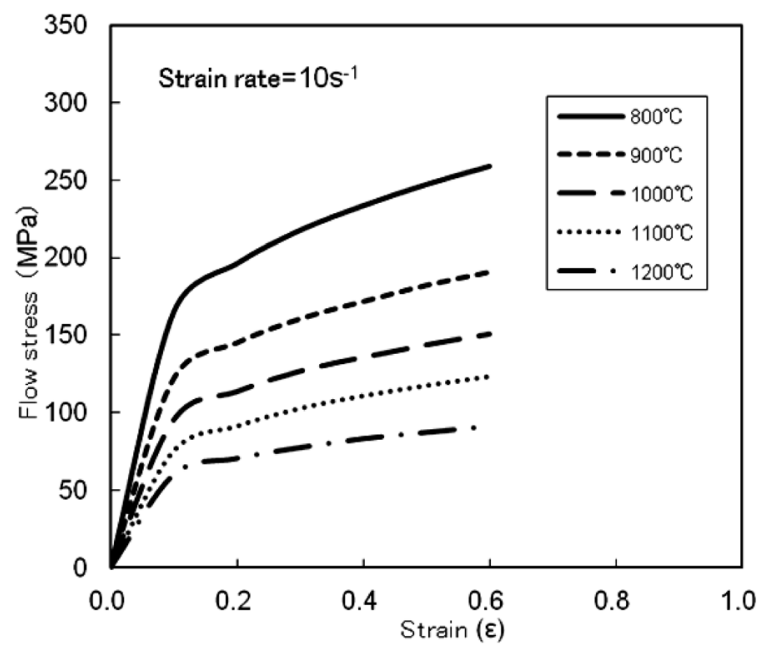

（a）鉄鋼材料 S25C （ひずみ速度 $10 \mathrm{~s}^{-1}$ ) $\beta$ 変態点 $(\alpha+\beta$ の 2 相域と $\beta$ 単相との遷移温度 $)$ が低下するた めに, $\alpha-\beta$ 鍛造 $(\alpha+\beta$ 相の 2 相域で鍛造する方法 $)$ の場合に は変形抵抗が高くなり, 鍛造時により大きな力量を要する。 したがって, 用途や要求特性に応じて, 適切な合金と鍛造方 法の組合せを選択する必要がある。

チタン合金と一般の鉄鋼材料の熱間加工における円柱圧縮 試験による応力ひずみ線図の例を図 2 に示す。鉄鋼材料が一 般に加工硬化挙動を示すのに対し, チタン合金においてはひ ずみの増加に伴い変形抵抗值が低下する挙動を示している。 この現象は $\alpha や \beta の$ 相によらず, 特に低温, 高ひずみ速度の 加工条件において顕著となる。

このような加工軟化挙動を示す材料においては, 最初に変 形が生じた部位の変形抵抗が下がるため, さらに加工を続け ると, その後もその部位が優先的に変形を続けることとな る。その結果, 鍛造品内部では不均一なひずみ分布が生じる こととなるほか, 型鍛造においては型充満が起こりにくくな る。また，チタンは比較的熱伝導率が低い材料であるため, 加工中のひずみの不均一によって加工発熱による温度分布が 維持増長されることにより, ひずみに加えて温度分布も不均 一となる。

一方，チタン合金鍛造品の代表的な製造工程は図3に示す 通りであるが，チタン合金では鍛造後の熱処理温度が通常 $\beta$ 変態点以下であるため, 鍛造ままの組織状態が製品の組織形 態,ひいては，特性に大きく影響を及ぼす。それゆえチタン

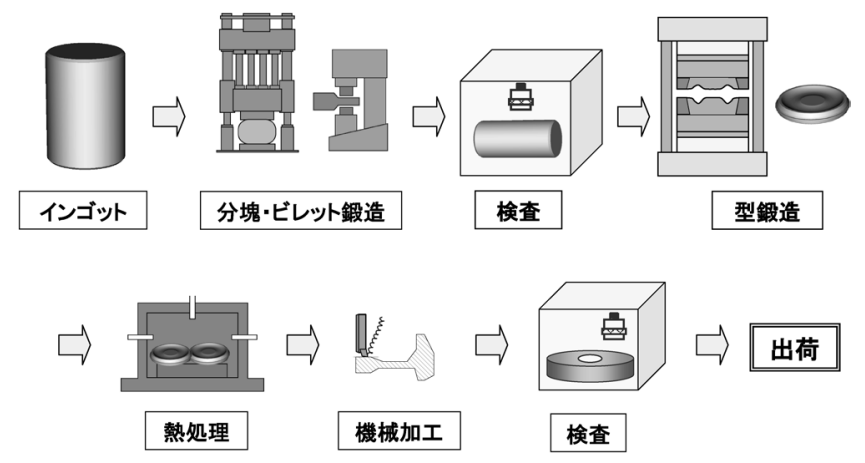

図3 チタン合金鍛造品の製造工程例

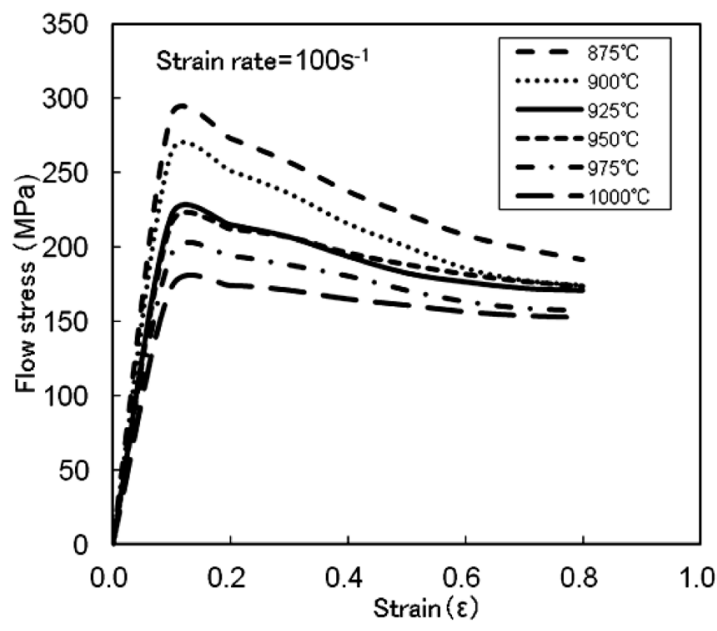

(b) チタン合金 Ti-6246（ひずみ速度 $100 \mathrm{~s}^{-1}$ )

図 2 チタン合金と鉄鋼材料の高温変形抵抗の模式図 


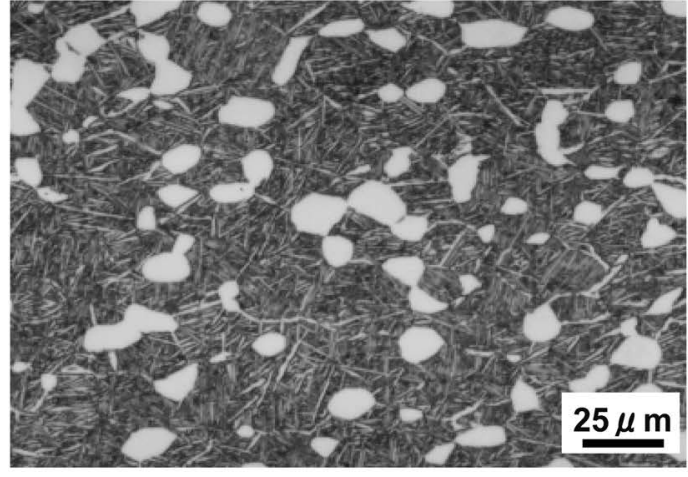

(a) $\alpha-\beta$ 鍛造

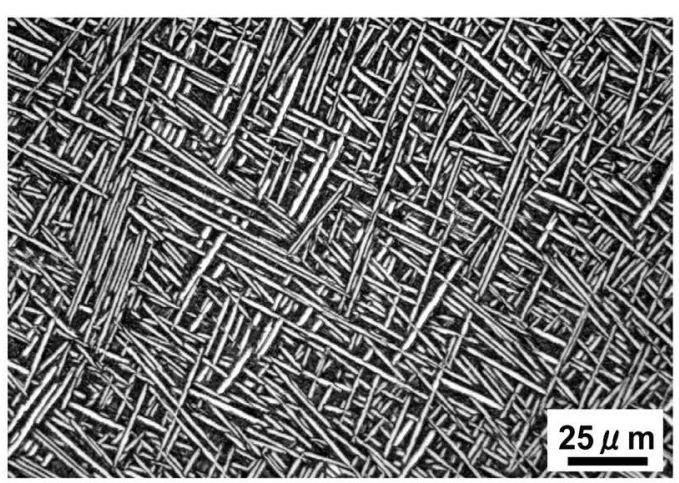

(b) $\beta$ プロセス鍛造

図4 Ti-6246合金のミクロ組織

合金では，製品形状を得ることのみならず，所望の組織・特 性を得るために，鍛造中の温度，ひずみ，ひずみ速度ならび に鍛造後冷却速度のコントロールが極めて重要になる。

ここでは，特に鍛造中の温度，ひずみの影響に着目し，具 体的な事例を取り上げながら, チタン鍛造品の工程設計の考 え方，ならびに，それに必要な技術について紹介する。

\section{4. チタン合金の熱間鍛造技術}

\section{1 航空機用Ti-6246 合金ディスクの $\beta$ プロセス鍛造}

前述の通り, 航空機用ジェットエンジンの圧縮機には軽量 高強度材としてチタン合金が多く用いられている。なかでも 外周部に動翼の付く回転体ディスク材には，高度な信頼性が 要求されるため鍛造品が使われている。デイスクに要求され る主要な材料特性は低サイクル疲労強度に加えて破壊勒性で あり，適用される合金のひとつがTi-6246である。

$\beta$ 変態点以下の温度域 $(\alpha+\beta$ 域 $)$ で鍛造加工する方法であ る $\alpha+\beta$ 域鍛造で得られる組織は伸長 $\alpha$ 粒が分断されて再加熱 により等軸化するため図4(a) のように等軸 $\alpha$ 粒とマトリッ クスが微細な針状 $\alpha$ を含む $\alpha+\beta$ の 2 相組織となるが, この組 織は延性や疲労強度には優れるものの, 亀裂伝播速度が速 く, 破壊勒性值が低いという特性上の課題がある。それを改 善する製造法として, $\beta$ 域加熱による鍛造法（以下， $\beta$ プロ セス鍛造法）がある。このプロセスで得られる組織は, 鍛造 中に $\alpha$ 相の析出が少なく, 鍛造後の冷却中に $\alpha$ 相が析出する ことで図4(b) のように全面針状組織となり，高い破壊靶性 值が得られる。従来の $\alpha+\beta$ 域鍛造ディスクの室温での破壊勒 性值が $30 \mathrm{MPa} \cdot \mathrm{m}^{1 / 2}$ レベルである ${ }^{7), 8)}$ のに対し， $\beta$ プロセス鍛 造材は $50 \mathrm{MPa} \cdot \mathrm{m}^{1 / 2}$ 以上の值が得られる ${ }^{9), 10) 。 ~}$

一方， $\beta$ プロセスにおいては，鍛造前の $\beta$ 域加熱により組 織が変態してそれまでの加工履歴の影響がほとんどなくなる ため, 鍛造材の特性は最終鍛造時の温度および加工ひずみに 大きく左右される。そのため, 適正な材料特性を得るために は, $\beta$ プロセス鍛造加工条件の高度な制御が必要となる ${ }^{11)} 。$

\section{$4.2 \beta$ プロセス鍛造の適正条件〜組織〜}

$\beta$ プロセス鉦造のコンセプトは, 延性と疲労強度を低下さ せる直線状の粒界 $\alpha$ の抑制と破壊鞁性を高める針状 $\alpha$ の促進 の観点から, 加工硬化させた $\beta$ 相から粒界への $\alpha$ 相の優先析 出を抑制することで全面的に針状の $\alpha$ 相を析出させることに ある。

図 5 に組織面からのプロセス条件範囲を示す。図の縦軸は
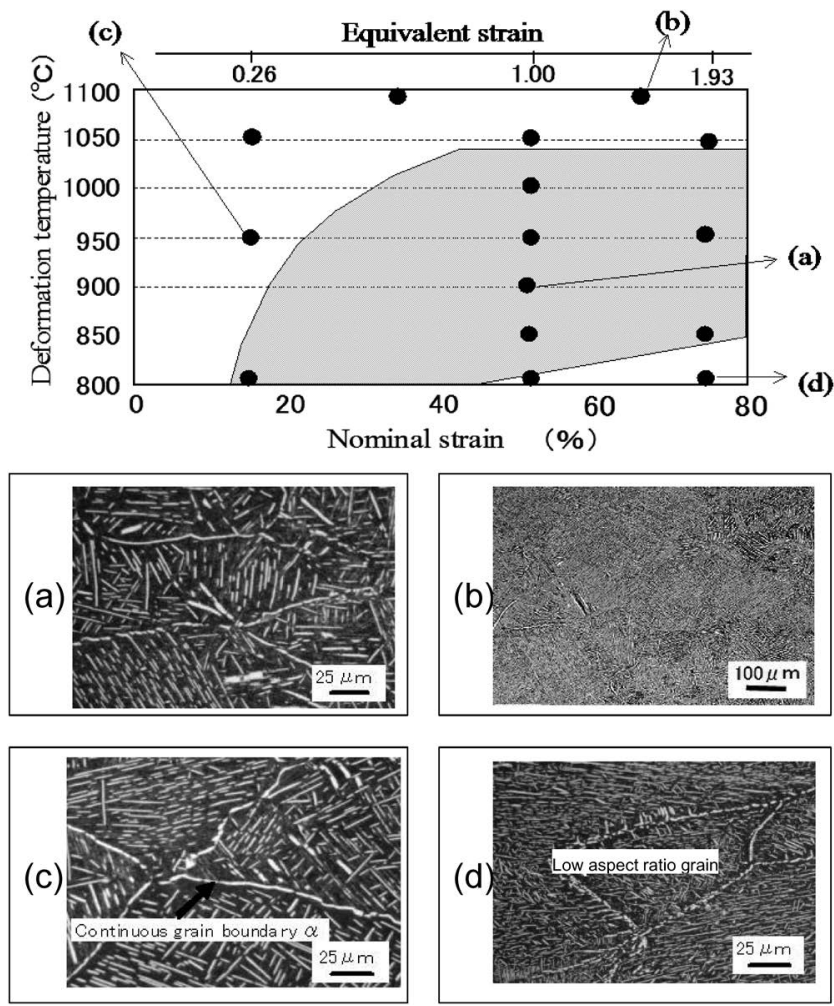

図 5 Ti-6246合金の $\beta$ プロセス鍛造条件とミクロ組織

加工温度, 横軸は圧縮率である。実験時の不均一ひずみを考 慮するために, 上部の横軸にはFEM解析により求めた組織 観察部（厚さ中心, 半径の $1 / 2 \mathrm{R}$ 部) の相当ひずみも示した。 図の下部に実験時の代表的なプロセス条件でのミクロ組織を 示す。温度が高い領域（b）では再結晶粗大 $\beta$ 粒が生成する。 また, 温度が低くても加工ひずみの少ない領域（c）では直 線状粒界 $\alpha$ の残留する組織となる。温度が低く, 加工ひずみ の大きい領域 (d) では針状 $\alpha$ のアスペクト比（長さと幅の比） が小さく，等軸化が進んでいる。このように粒内の $\alpha$ 組織が 等軸化してしまうと, $\alpha+\beta$ 域鍛造材の組織と同様になるため 破壊勒性值が低下し，亀裂伝播速度も速くなる。

これに対し, 四5のハッチングを施したプロセス条件範囲 では写真（a）に代表されるように, 粒界 $\alpha$ が不連続であり， かつ粒内はアスペクト比の大きい（細長い）針状組織が得ら れ，破壊䩲性が向上できる。 


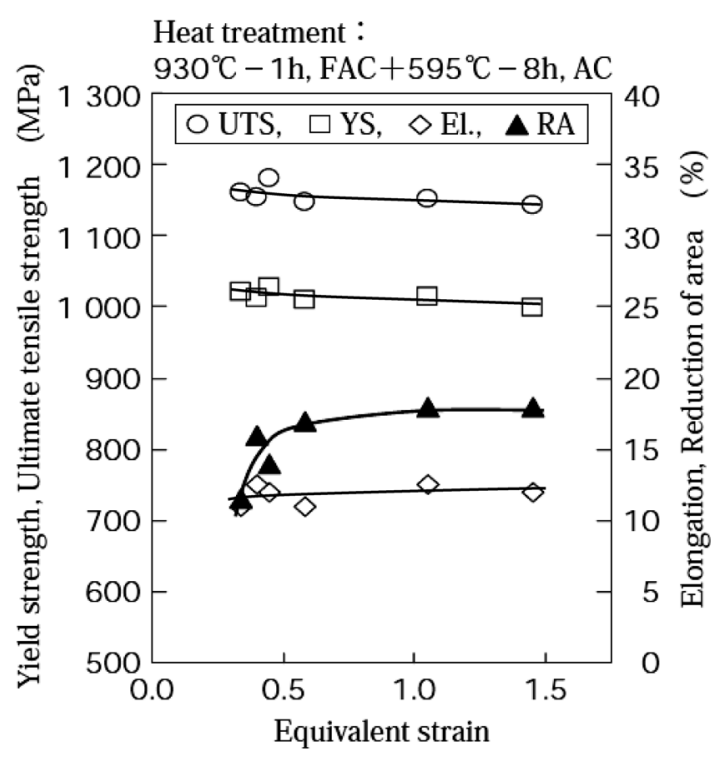

（a）引張特性

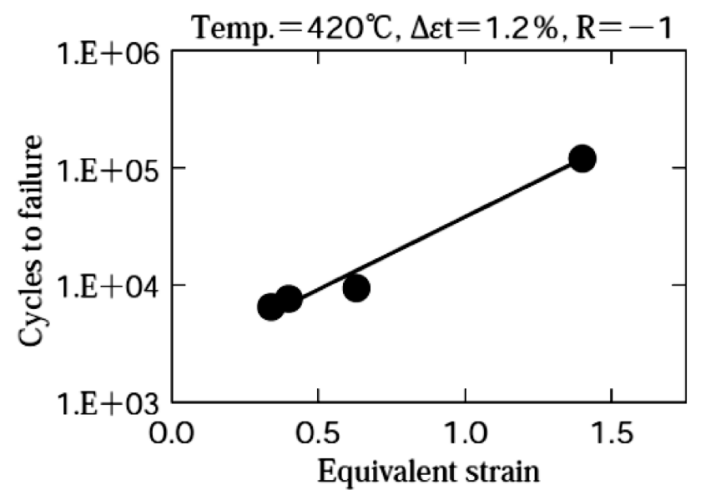

（b）低サイクル疲労寿命（LCF : Low cycle fatigue）

図6 Ti-6246合金 $\beta$ プロセス鍛造材の材料特性と相当ひ ずみの関係

表 $1 \beta$ プロセス円柱圧縮鍛造材の破壊鞁性試験結果（室 温)

\begin{tabular}{c|c|c}
\hline \hline 圧縮率 $(\%)$ & 33 & 67 \\
\hline 破壊靸性值 $\left(\mathrm{MPa} \cdot \mathrm{m}^{1 / 2}\right)$ & 69.9 & 64.5 \\
\hline
\end{tabular}

\section{$4.3 \beta$ プロセス鍛造の適正条件〜材料特性〜}

前節の鍛造条件が金属組織に及ぼす影響に加え，材料特性

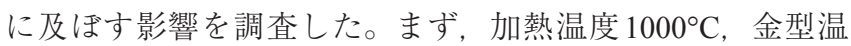
度 $850^{\circ} \mathrm{C}$ の条件で，圧下率を $33 \%$ と $67 \%$ に変えた圧縮加工を 加えることにより外径 $\phi 230 \times$ 厚さ $80 \mathrm{~mm}$ の円柱圧縮鍛造材を 作製して機械的特性を調査した。

引張試験片は鍛造材の厚さ中心 $(1 / 2 \mathrm{t}) ， 1 / 4 \mathrm{t}$ ，表層 $10 \mathrm{~mm}$ の各位置から引張軸が接線方向となるように切出した後, $930^{\circ} \mathrm{C}, 1 \mathrm{~h}$ の溶体化および $595^{\circ} \mathrm{C}, 8 \mathrm{~h}$ の時効処理を施した試料 を用いて試験した。

図6(a) に，圧縮率33\% と 67\%の鍛造材の各試験片位置の 相当ひずみを FEM解析により求め，相当ひずみに対する室 温引張特性を示した。引張強度（UTS，，降伏強度（YS）に は相当ひずみの影響は見られないが，絞り值（RA）は相当

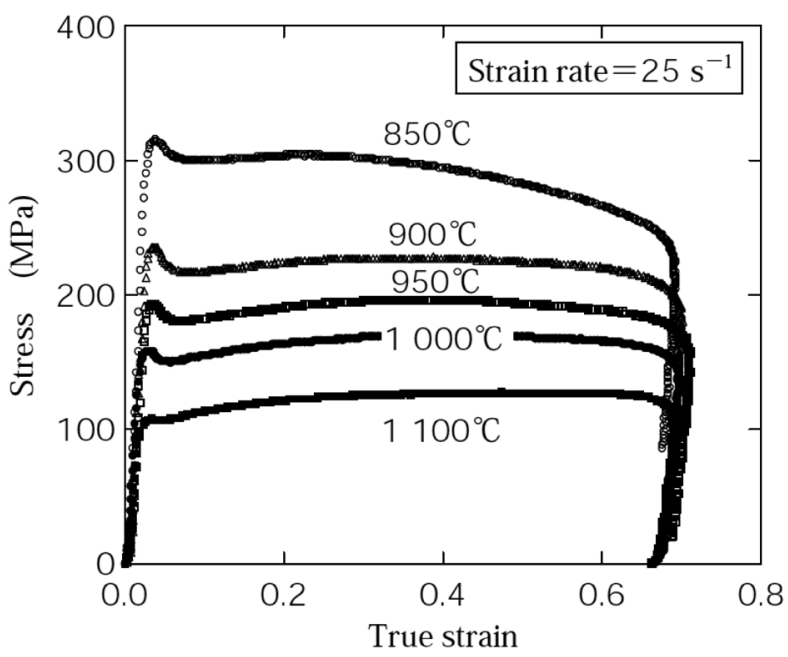

図7 Ti-6246の圧縮応力ひずみ線図

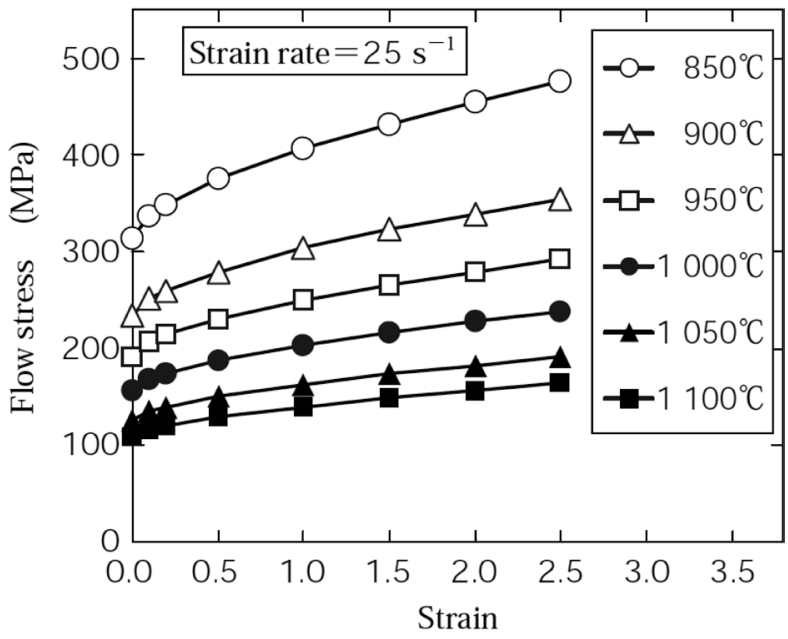

図8 Ti-6246の恒温変形抵抗

ひずみが 0.5 以下で低下する。したがって, 十分な延性を確 保するためには, 少なくとも 0.5 以上の相当ひずみを加える 必要がある。

図6(b) にジェットエンジンのディスク材で重要な特性の ひとつである低サイクル疲労（LCF）の破断寿命に対する相 当ひずみの影響を示した。破断寿命は相当ひずみが大きくな ると向上する傾向がある。相当ひずみが少ない場合は延性が 低いこと，および鍛造相当ひずみの少ない直線状粒界 $\alpha$ を持 つ組織では, 負荷応力による転位が粒界 $\alpha$ に堆積しやすいた めに疲労亀裂の発生が粒界 $\alpha$ に沿って起こることで, 疲労寿 命が短くなると考えられ, 疲労強度向上のためにもより加工 ひずみを加えることが望ましいことがわかる。

また，室温での破壊勒性值は表 1 に示す通り，ひずみ量に よらず $60 \mathrm{MPa} \cdot \mathrm{m}^{1 / 2}$ 以上の高い数值が得られている。

\section{4 アプロセス鍛造解析技術による工程設計}

上述のように適正条件範囲に温度, ひずみを制御しなが ら目標のディスク形状を得る鍛造工程を決定するためには FEM変形一温度連成解析による温度・ひずみ予測を活用する ことが不可欠である。このFEM解析を高精度に行うために 重要な項目のひとつがFEM解析に適用する変形抵抗データ の取扱いである。

円柱圧縮試験での荷重-ストローク測定結果から Ti-6246 

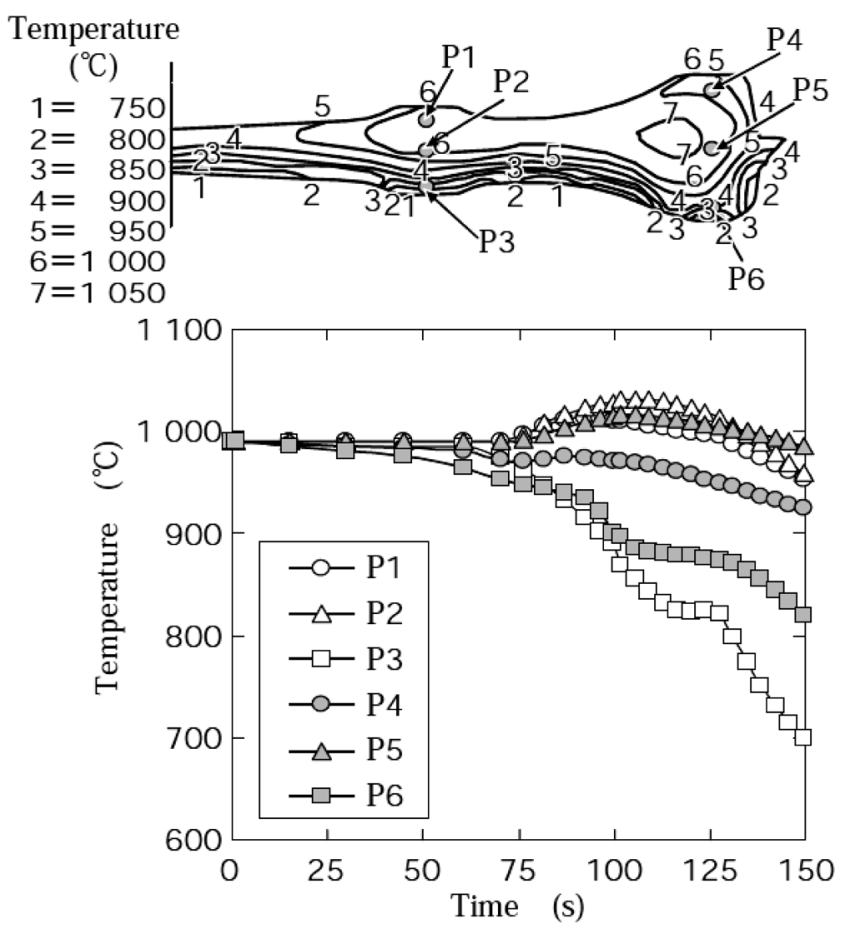
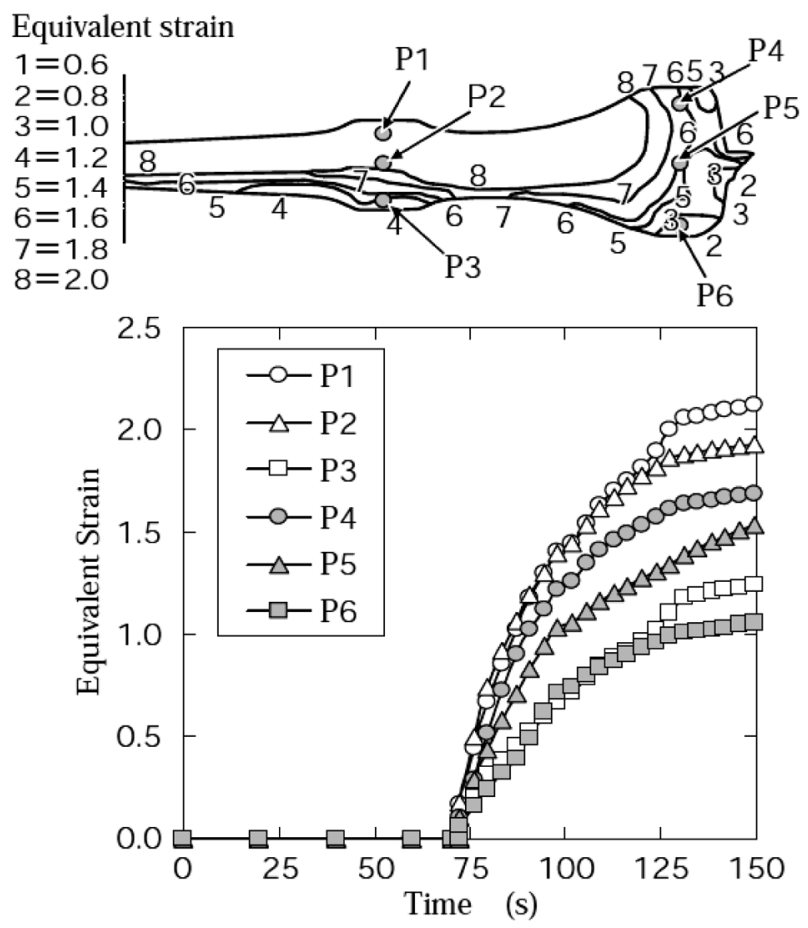

図 9 ディスク部品 $\beta$ プロセス鍛造の温度およびひずみ解析結果

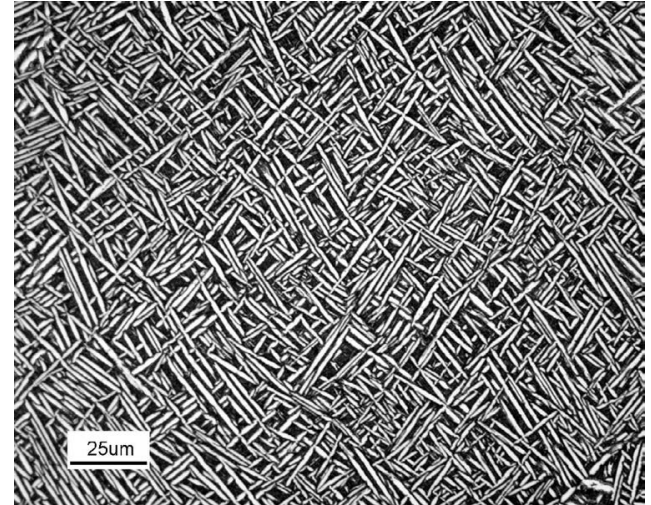

図 10 Ti-6246 $\beta$ プロセス鍛造ディスクのミクロ写真

の応力ひずみ線図を作成すると図7のようになり，前述の通 り，特に低温では加工軟化の様相を示す。しかし，実際には 加工発熱による試験片素材の温度上昇があるため, 温度变化 の影響を受けた結果である。FEMによる変形ー温度連成解析 では, 加工発熱は別途計算されているため変形抵抗值として は温度一定 (恒温) 条件での值が必要である。そこで，下記 の手法により加工発熱による温度上昇の影響を取り除いた。

まず，変形抵抗 $\sigma$ とひずみ $\varepsilon$ の関係式を式(1) のように仮 定した。

$$
\sigma=A(T) \times\left(1.0+F \varepsilon^{n}\right)
$$

ここで, $A(T)$ : 初期変形抵抗值（温度 $T$ とひずみ速度の関 数), $n$ : 加工硬化指数, $F$ : 係数である。

低ひずみ域であれば加工発熱の影響が少ないため, 図 7 の 応力ひずみ線図の降伏点から変形抵抗の温度とひずみ速度 依存性デー夕を構築し, 式 (1) の $A(T)$ を決定する。次に, 圧縮試験のストロークー荷重線図と一致するように，変形一 温度連成解析を行って, 加工硬化指数 $n$ と係数 $F$ の最適化を

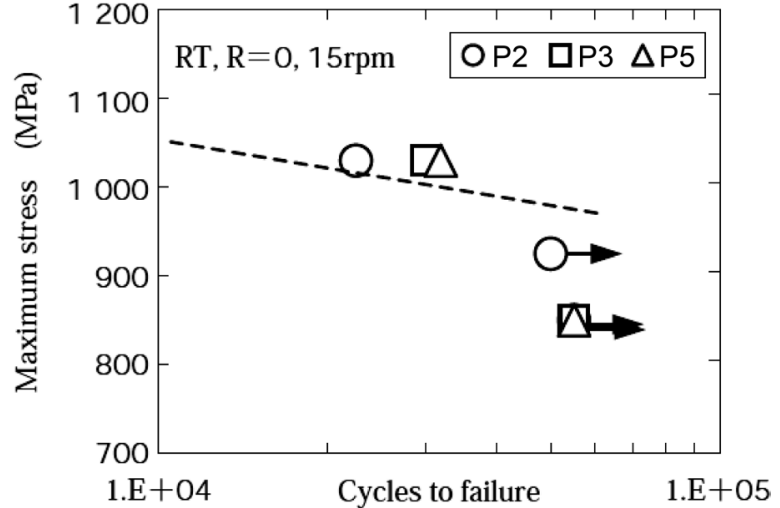

図11 ディスク試作品の低サイクル疲労試験結果

表 2 ディスク試作品の破壊鞎性試験結果

\begin{tabular}{c|c}
\hline \hline 評価位置 & 破壊鞎性值 $\left(\mathrm{MPa} \cdot \mathrm{m}^{1 / 2}\right)$ \\
\hline P2 & 58.6 \\
P3 & 65.4 \\
P5 & 68.1 \\
\hline
\end{tabular}

行った。以上により得られた式(1) を用いることで, 図8に 示すように各温度, ひずみ速度, ひずみにおける恒温変形抵 抗が算出可能となる。

恒温変形抵抗データを適用したFEM解析により, 直径 約 $700 \mathrm{~mm}$ の実鍛造ディスク品を対象にしてプロセス設計を 行った。図9に決定した $\beta$ プロセス鍛造条件における鍛造後 の形状，温度・相当塑性ひずみ分布および，鍛造品各部位に おける鍛造中の温度, 相当塑性ひずみ履歴の解析結果を示 す。各部位において, 組織, 材料特性の観点から求めた適正 条件範囲内にて変形が完了している。

以上のような工程設計技術を適用して試作を実施した鍛造 
品の組織写真の一例を図 10 に示す。また，表2に代表点に おける室温での破壊鞁性測定結果を示す。ここで，表中の評 価位置記号は図9に示す FEM解析の出力点に相当する。鍛 造品の肉厚中心部で塑性ひずみの最も大きくなる $\mathrm{P} 2$ 点にお いて相対的に低くなっているものの，このような針状 $\alpha$ 組織 とすることで，いずれも $50 \mathrm{MPa} \cdot \mathrm{m}^{1 / 2}$ を超える高い室温破壊 勒性值が得られていることが確認できる。また, 低サイクル 疲労強度に関しても図11に示すように，部位による差異の 少ない，良好な評価結果が得られている。

\section{5. 結言}

本稿では，航空機エンジン用ディスクの鍛造事例を中心 に, チタン合金鍛造品の特徴となる鍛造技術について紹介し た。チタンは温度，ひずみの精緻な制御による組織，材料特 性の造り込みが必要な, 加工の難しい材料である反面, 鍛造 技術による差別化の余地が大きい材料であると言える。

日本国内では，2013年から日本エアロフォージ株式会社 において待望の超大型 5 万トンプレスが稼働し始めた。これ を活用することで，日本の航空機向けチタン合金鍛造品の生 産量が今後一層向上することが期待されている。
そのためにも，形状や温度に留まらず鍛造後の組織や材料 特性の高精度な予測も可能とする解析技術の構築, ならび に, チタンに代表されるような熱間難加工材の鍛造技術のさ らなる高度化が望まれる。

\section{参 考 文 献}

1) 荒木重臣：チタン, 57 (2008), 3-7.

2) 森口康夫 : 金属, 82 (2012), 211-217.

3) 長田 卓, 大山英人, 村上昌吾： R\&D 神戸製鋼技報， 64-2 (2014), 28-32.

4) R. R. Boyer, K. T. Slattery, D. J. Chellman and H. R. Phelps: Ti-2007 Science and Technology, Vol. 2 (2007), 1255-1262.

5）村上昌吾, 大山英人：金属, 83-4 (2013)，33-39.

6) 林 利昭, 西村 孝, 湯口 弘, 津守芳勝： $R \& D$ 神戸製鋼技報, 32-1 (1982)， 36-39.

7) 西村 孝, 安価健一, 矢野博俊, 松本年男, 津森芳勝 : R\&D 神戸製鋼技報，34-2（1984），89-92.

8) H. Yano, et al.: Titanium Science and Technology, (1984), 507

9) T. Krull, et al.: Ti-2003 Science and Technology, Vol. III (2003), 1871.

10) G. Terlinde, et al.: Ti-2003 Science and Technology, Vol. V (2003), 2891.

11) 石外伸也, 百田悠介, 村上昌吾, 前田恭志, 長田 卓： $R \& D$ 神戸製鋼技報，55-3（2005），52-56. 